\title{
新しい検眼用フレームの開発と試用経験
}

清水みはる ${ }^{1)}$ ・稲泉令巳子 ${ }^{1)}$ ・寺本恵美子 ${ }^{1)}$ ・澤 ふみ子 ${ }^{11}$ 中村 桂子 ${ }^{1)} \cdot$ 内海 隆 ${ }^{1)} \cdot$ 上野 正人 ${ }^{21}$

1) 大阪医科大学眼科学教室

2) 増永眼鏡株式会社

\section{Development and Clinical Trial of A New Trial Frame for Ophthalmic Use}

Miharu Shimizu $^{1)}$, Remiko Inaizumi ${ }^{1}$, Mieko Teramoto ${ }^{1)}$, Fumiko Sawa ${ }^{1)}$ Keiko Nakamura ${ }^{1)}$, Takashi Utsumi ${ }^{1)}$, Masato Ueno ${ }^{2)}$

1) Department of Ophthalmology, Osaka Medical College

${ }^{2)}$ Masunaga Optical Mfg. Co., Ltd

要 約

検眼用フレームとして現在普及しているものはフィット感や重さ, 酎久性が十分とは言い難く, 満足できるのがないのが現状である。そこで使いやすさや酎久性を重視し, またカラフルな色彩を 採用した検眼用フレームの開発・改良に参加し, 試用する機会を得たので報告する。対象は平成 8 年 2 月 1 日から同 9 月 30 日までの 8 ヶの間に大阪医科大学附属病院眼科外来を受診した患者のう ち, 無作為に抽出した2980名と高梘市 3 歳児検診を受診した350名である。方法は従来からの固定

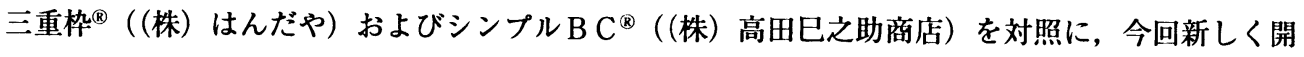
発した検眼用フレーム（増永眼鏡（株））と比較検討した。新しいフレームは材質としてホルター 部分には抗菌作用や耐磨耗性, 強勒性のあるエンジニアリングプラスチックを用い, 金属部分には チタンを使用しているのでかなり軽量である。フィッティングを良くするための独自の工夫と子供 が受け入れ易いように配慮したカラフルな色彩が特徵である。結果として, 新しいフレームはレン ズの装着感が良く, 検者側からの評価も高く, 患者の満足度も十分で, 眼鏡処方時の長時間の装用 テストにおいても好評であった。明るい色合いは小児に特に好まれた。今後の実用化が期待される。

連絡先（T569）高柣市大学町 $2-7$

大阪医科大学 眼科学教室 清水 みはる

Tel. $0726-83-1221$

Key words : Trial frame, Engineering plastics, Colored design, Lightweight, Durability 


\section{Abstract}

Trial frames for ophthalmic use popularly utilized in Japan are lack of comfort, lightness, and durability, and are generally not satisfactory. Therefore, we joined with Masunaga Optical Mfg. Co., Ltd. in the development of a New Trial Frame to resolve the problems and made a clinical trial on a large number of subjects after obtaining their informed consent.

The 2,980 subjects were randomly selected from the outpatients who visited our ophthalmic clinic in the Osaka Medical College Hospital from February 2 to September 30 in 1995.

350 three-year-old children who visited the clinic to check the visual acuity as a social examination during the above-stated period were also included in the trial.

We compared the New Trial Frames to the traditional frames of Fixed Triple Frames ${ }^{(1)}$ (HANDAYA) and Simple BC Frames ${ }^{\circledR}$ (TAKADA MINOSUKE SHOUTEN). The New Trial Frames by Masunaga Optical Mfg. CO., Ltd. were made with engineering plastics. The features of the plastics are anti bacterial properties and scratch resistant surfaces as well as durability.

A titanium alloy as a metalic part was used because of light weight. The comfort of fitting was improved by their unique ideas. Bright colored designs were employed to enlist the children's enthusiastic cooperation. As a result, the New Trial Frames gave a suitable comfort to the subjects and a favorable impression to us. The subjects were well satisfied with the New Trial Frames even after the long trial before prescribing the glasses. The bright color of the Frames was widely preferred by the children. Further widespread and practical use of the New Trial Frame is expected.

\section{I．緒言}

検眼用フレームは, 日常臨床において重要で 欠くことのできない眼科器材である。各メーカ 一でも日々改良が重ねられているが, 現在普及 しているフレームではフィッティングや重さ, 材質，耐久性など，十分に満足いくものがない のが現状である。また，特異性のある小児の顔 立ちへの配慮が足りないことや ${ }^{11}$, 眼鏡処方時 の装用テストでのクレームが目立ち，レンズホ ルダーの安定性, 鼻パッドやテンプル・モダン などの形や材質の改良が望まれていた。

そこで使いやすさや酎久性を重視し，またカ ラフルな色彩を採用した新しい検眼用フレーム の開発, 改良に参加し, 試用する機会を得たの で報告する。

\section{II. 対象および方法}

対象は, 平成 8 年 2 月 1 日から同 9 月 30 日ま での 8 ケ月の間に大阪医科大学附属病院眼科外 来を受診した患者のうち，無作為に抽出した 2980名（3 歳〜78歳, 平均33.4歳）である。い ずれも屈折異常あるいは老視を有し，レンズ交
換法による $5 \mathrm{~m}$ 矯正視力検査および遠用眼鏡処 方時，あるいは近用眼鏡処方時に試用した。ま た，高㭇市における 3 歳児検診においても，小 児に対する適応性に重点をおいて評価するため に350名に試用した。 8 ケ月の試用期間中，1〜 2 ヶ月毎に計 5 回の改良を繰り返し加えた。

方法としては, 従来からの固定三重枠 ((株) はんだや）およびシンプル B C ${ }^{\circledR}$ ((株) 高田巳 之助商店）を対照とし, 今回新しく開発した検 眼用フレーム (増永眼鏡 (株)) と比較し, わ れわれ検者側からの使用時の評価のみならず, 被検者側からの装用感についても検討した。

今回新しく用いた検眼用フレームは, 既存の フレームの欠点を改良するためにフィッティン グ, 軽量性, 材質, 使いやすさ, 耐久性, 色彩 などを考慮したもので ${ }^{2)}{ }^{3)}$ ，材質としては抗菌 作用，耐磨耗性ならびに強靫性をもつエンジニ アリングプラスチック（レンズホルダーやモダ ン部分にはポリアセタール樹脂，鼻パッドには エチレンーメタクリル酸共重合体） ${ }^{4}$ 用い, 金 属部分にはチタン合金を用いた（図 1)。

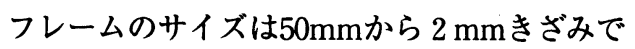
$68 \mathrm{~mm}$ までの10サイズとした。小児用に $50 \mathrm{~mm}$ 以 


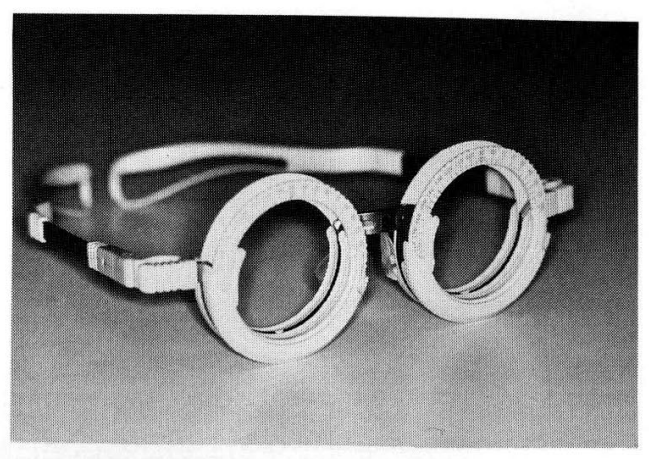

図1．新しい検眼用フレームの全景

下のフレームも検討したが, レンズホルダーの 安定性を重視した設計のため左右のレンズ枠が 太く接触し合うので, $50 \mathrm{~mm}$ 以下の小さなフレ ームの作製は不可能であった。カラーは, 従来
の暗く硬いイメージを変え，とくに子供が受け 入れやすいように配慮してピンク, ブルー, イ エロー,グレー, ベージュの 5 色とした。ただ し，50mmから54mmの小児用フレームでは，子 供が好む色合いであるピンク，ブルー，イエロ 一の 3 色とした。

\section{III. 結 果}

今回新しく作製した検眼用フレームと従来の 検眼用フレームの検者側からの評価を表 1 に示 す。新しいフレームは，フィッティングが良く フレームが軽いために, 検査時の患者への負担 が軽く評価が高かった。検眼枠の重量の比較を 行うと（表 2), 私たちが使いやすいと考えて いた固定三重枠はP D64mmで45gであるのに対 し, 新しい検眼用フレームは $32 \mathrm{~g}$ となり, 約 $30 \%$ 減少がみられる。小巟用として超軽量と

表 1 . 検者側からの評佂

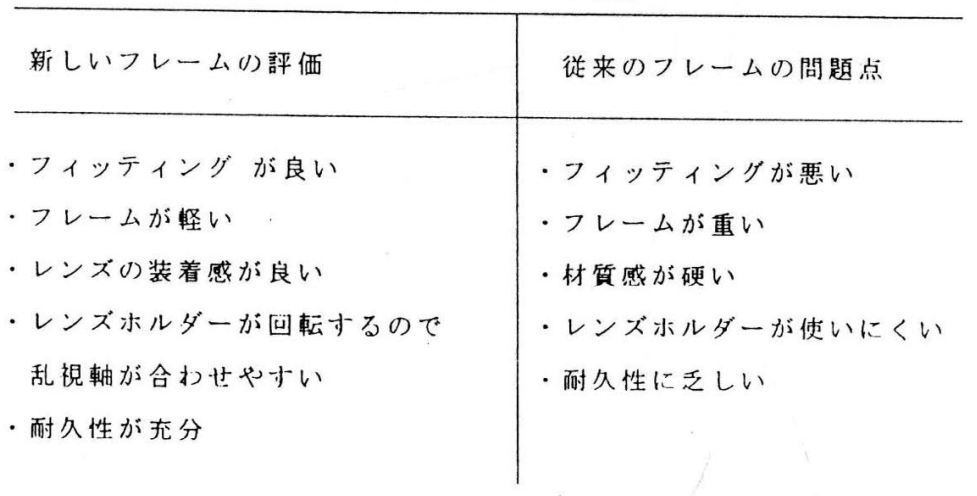

表 2 . 検眼枠の重量の比較

\begin{tabular}{|c|c|c|l|}
\hline $\begin{array}{l}\text { P D } \\
(\mathrm{mm})\end{array}$ & 固定三重枠 & シンプル B C & $\begin{array}{l}\text { 新しい } \\
\text { 検眼用フレーム }\end{array}$ \\
\hline 64 & $45 \mathrm{~g}$ & $35 \mathrm{~g}$ & $32 \mathrm{~g}$ \\
\hline 60 & $44 \mathrm{~g}$ & $35 \mathrm{~g}$ & $31.5 \mathrm{~g}$ \\
\hline 52 & $44 \mathrm{~g}$ & $31 \mathrm{~g}$ & $31 \mathrm{~g}$ \\
\hline
\end{tabular}


いうことで市販されているシンプル B Cでは, 重量の点で新しい検眼用フレームとほほ同等で あり， P D52mmで31gとなっているが，ホルダ 一部分の安定性に欠け，後述のように堅牢性に 問題があった。新しい検眼用フレームは，レン ズホルダーにエンジニアリングプラスチックを 使用しているためにレンズの装着感が良く，3 枚のレンズを安定して入れることが可能であり， 材質感が硬いという従来のフレームのもってい た難点もみられなかった。レンズホルダーが回 転するので乱視矯正時に軸の回転に制限がなく， 乱視軸を合わせやすかった。耐久性についても， 従来のフレームと比較してはるかに堅牢で, 充 分な耐久性をもっているように思われた。

被検者の装用感を比較し, 表 3 に示した。フ イッティングの良否, フレームの重さ (軽量性), 鼻パッドのフィット感, モダンのフィット感な らびに耳介部への負担においては評価が高く， 大部分の患者が新しいフレームが良いと答えた $(\mathrm{P}<0.01$, フィッシャーの正確確率検定)。色 彩に関しては，明るい色合いが小児用として好
評で， 3 歳時検診においてもアイパッチよりこ の新しい検眼枠を選ぶ小児が多かった（ $\mathrm{P}<$ 0.01 , 同上)。しかし成人においては明るい色合 いは軽く見られ，あまり好まれず，グレーやべ ージュといった従来からの検眼用フレームの色 合いが好まれた。また，眼鏡処方時の長時間の 装用テストにおいては，側頭部の形状に沿った テンプル・モダンのフィッティングの良さのた め, 鼻にかかる重さが軽減され, 動きに対して も安定感が良く, 好評であった。テンプルの長 さ, フレームのデザインそのものについては被 検者の評価が分かれていた。ただレンズの安定 性を求めたためにレンズホルダー部分に厚みが あり，装用時に視野の狭さを感じるという反応 も多かった。

\section{IV. 考按}

\section{1. 従来のフレームの問題点}

図 2 に示すように，鼻パッドは材質が堅いた め鼻根部が発赤して痛みを訴えることをしばし ば経験する。また, 上段の固定三重枠『は鼻パ

表 3 ．被検者の装用感の比較 $(*: \mathrm{p}<0.01)$

\begin{tabular}{|c|c|c|c|c|c|}
\hline \multirow{2}{*}{\multicolumn{2}{|c|}{ チェックポイント }} & \multirow{2}{*}{$\begin{array}{l}\text { 新しいフレーム } \\
\text { の方が良い }\end{array}$} & \multicolumn{2}{|c|}{ 従来のフレームの方が良い } & \multirow{2}{*}{ どちらでもない } \\
\hline & & & 固定三重枠 & プル B C & \\
\hline \multicolumn{2}{|c|}{ フィッティングの良否 } & $2946^{\circ}$ & 8 & 6 & 20 \\
\hline \multicolumn{2}{|c|}{ フレームの重さ（軽さ） } & $2166^{*}$ & 0 & 525 & 289 \\
\hline \multicolumn{2}{|c|}{ 鼻パッドのフィット感 } & $2046^{*}$ & 147 & 316 & 471 \\
\hline \multicolumn{2}{|c|}{ モダンのフィット感 } & $2604^{\circ}$ & 123 & 107 & 146 \\
\hline \multicolumn{2}{|c|}{ 耳介部への負担 } & $2447^{\circ}$ & 51 & 141 & 341 \\
\hline \multicolumn{2}{|c|}{ 眼鏡処方時での長時間装用度 } & $2752^{\prime}$ & 76 & 51 & 121 \\
\hline \multirow{2}{*}{ フレームの色 } & 小児用として & $2958^{\circ}$ & 3 & 8 & 11 \\
\hline & 成人用として & 502 & 627 & 410 & 1441 \\
\hline \multicolumn{2}{|c|}{ テンプルの長さ } & 314 & 338 & 335 & 1993 \\
\hline \multicolumn{2}{|c|}{ フレームのデザイン } & 367 & 357 & 366 & 1890 \\
\hline \multicolumn{2}{|c|}{ 装用時の視野の広さ } & 542 & 536 & $1873^{\circ}$ & 30 \\
\hline
\end{tabular}




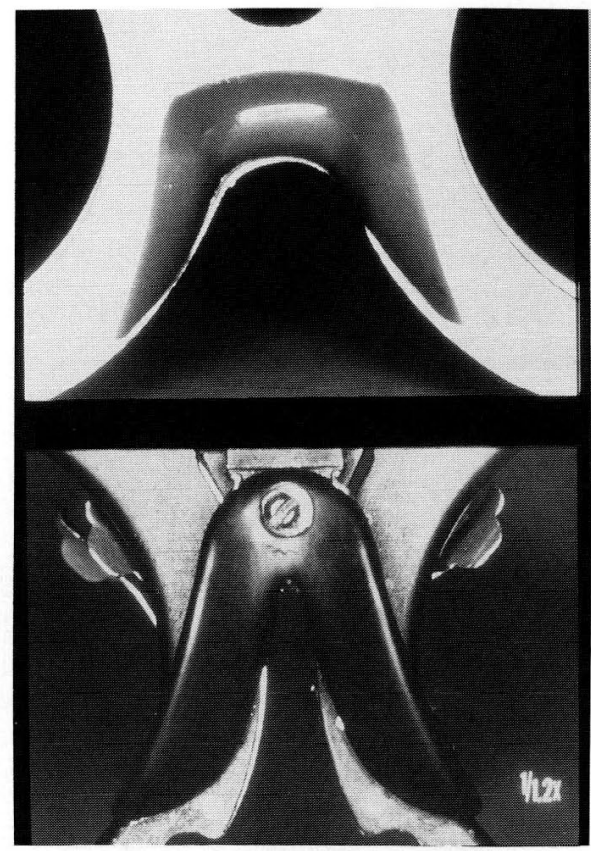

図 2. 従来の検眼用フレームの鼻パッド

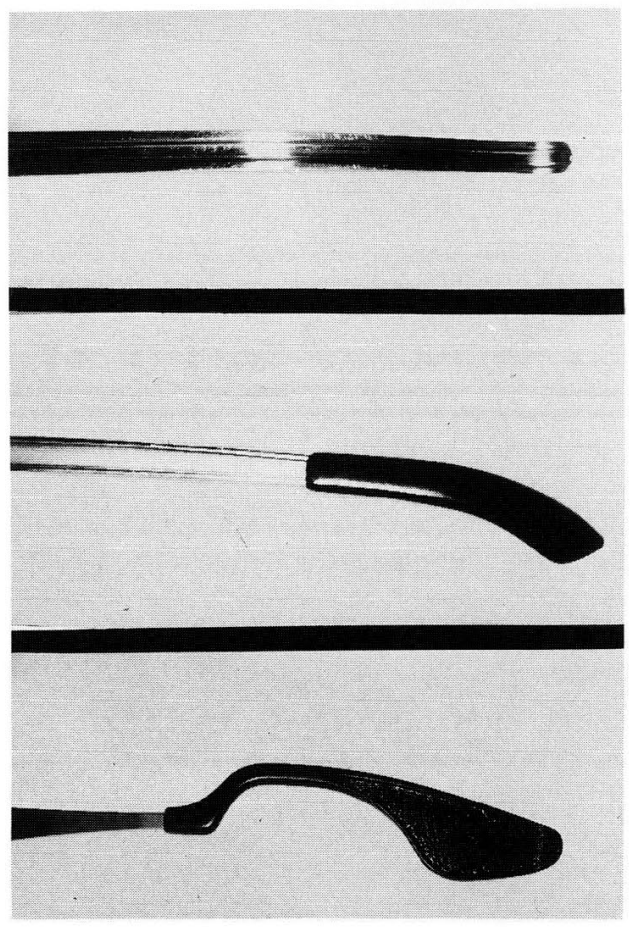

図 3. 従来の検眼用フレームのテンプル・モダン
ッドの接着面がもろくてとれやすく，耐久性に 問題があった。

図 3 にテンプル・モダンを示す。上段のイナ ミの検眼枠はバネ性のない金属でできていて， 頭の形状に対する配虑が足りないために耳に接 する部分が発赤し，痛みを訴えることがある。 中段や下段に示す固定三重枠『およびシンプル $\mathrm{B}$ $\mathrm{C}^{\circledR}$ は，バネ性やモダンの形状に対する配虑はあ るがまだ十分なものとは言えず，装用感が良く ない。

レンズホルダー（図 4) については，上段の 固定三重染『は枚のレンズを一度に装用できる 検眼染で，現在最もよく用いられているタイプ のものである。しかし, フレーム自体の重量が P D60mmのサイズで44gとかなり重く,ささらに ホルダー部分の回転ができないために乱視軸の 動きに制限があるのが久点である。下段のシン

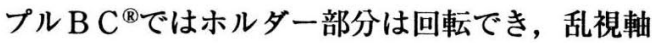
も自由に動かすことができるが，レンズを支え る部分が弱く, 安定感にそしく使いにくい。

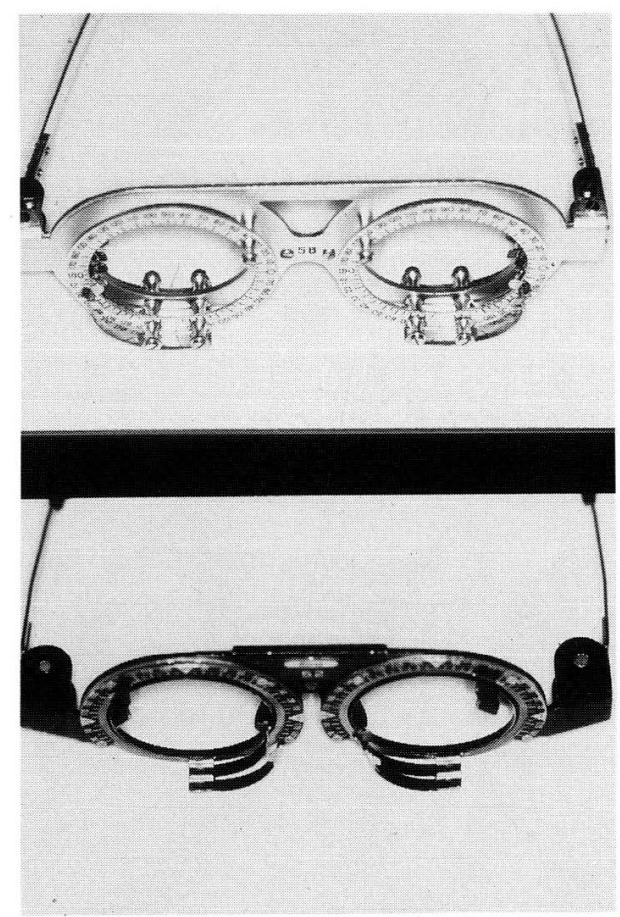

図 4. 従来の検眼用フレームのレンズホルター 


\section{2. 今回の試用経験からみた比較}

検者サイドからの評価としては, 新しいフレ ームはフィッティングが良好, フレームの重量 もかなり軽量, 検査時のレンズの装着感が良く, 乱視軸が合わせやすいという良好なものであっ た。

次に被検者の装用感としては, 新しい検眼用 フレームはフィッティングやフレームの軽量性 においては評価が高く, カラフルな色彩が小児 用として好評で， 3 歳児検診に有用であった。 しかし成人用としてはピンク，ブルー，イエロ 一はあまり好まれず, グレー, ベージュという 従来からある地味な色が好まれた。その他, 装 用時の視野が狭いという自覚を訴える人も多か った。

3. 新しい検眼用フレームの個々のパーツの 特幑

新しい検眼用フレームの個々のパーツの特徵 をあげる。

1) 鼻パッド (図 5 )

材質にエンジニアリングプラスチックを使用 しているために弾性があり，あたりがやさしく て装用感に優れる。また鼻パッドには 3 種類の 形があり，交換も可能である。

2 ）テンプル・モダン (図 6)

側頭部の形状に沿って頭を包み込むように設 計され, 耳下方への重みも軽隇されて装用感が 良好である。大きく二段のカーブをつけること により，側頭部に沿うように工夫されている (上段)。モダンの形状としては，上部の幅を広 くすることにより強度と安定性をもたせ，下部

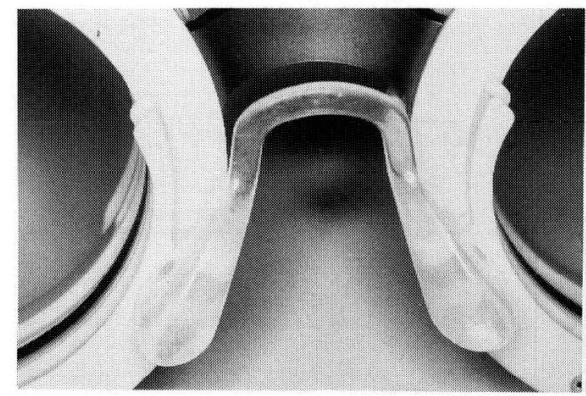

図 5. 新しい検眼用フレームの鼻パッド
を細くすることによって耳へのあたりをやさし くする工夫をしている (下段)。

3 ）レンズホルダー (図 7 )

ホルダー部分にネジを使用していないため緩 みにくく，耐久性に優れている。プラスチック の弾性を利用しているため, 厚みのあるレンズ の場合は金属性の枠よりもレンズの装着性が良 い。最前列のレンズホルダーは360度回転し， 5 度ごとにストッパーが付いている。

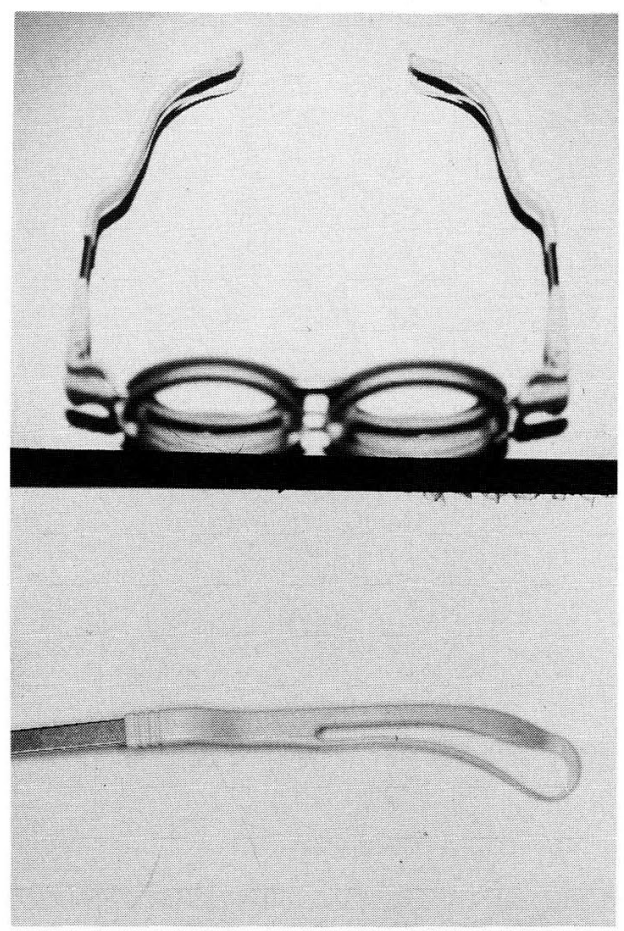

図 6. 新しい検眼用フレームのテンプル・モタン

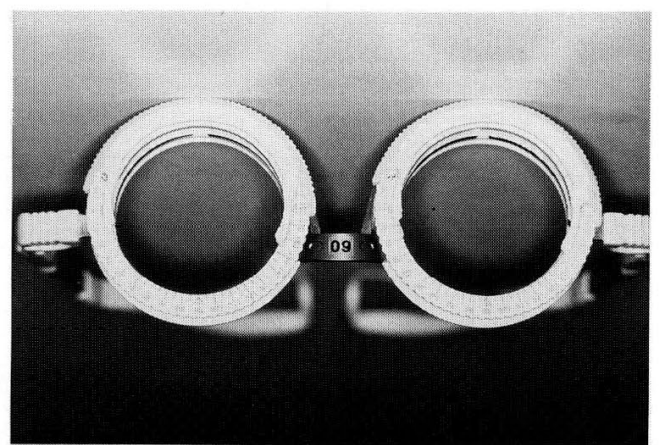

図 7. 新しい検眼用フレームのレンズホルダー 
4) よろい丁番（図 8)

エンジニアリングプラスチックの弾性を利用 したバネ機構によりフィット感を高めてある。 ネジのない方式を採用したため緩みの心配がな い。

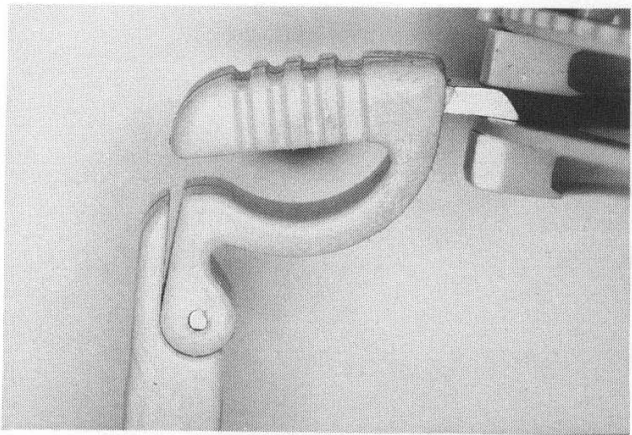

図 8．新しい検眼用フレームのよろい丁番

\section{V。まとめ}

大阪医科大学附属病院眼科外来を受診した患 者2890名と高柣市 3 歳児検診を受診した 350 名 に, 新しい検眼用フレームを開発し試用したと ころ,フィッティングや軽量性に優れていて患 者の満足度は高く, 眼鏡処方時の長時間の装用 テストにおいても好評であった。色彩がカラフ ルなため小児への人気も高く，視力検查がスム ーズに行えるようになった（図 9 )。今後の普 及が期待される。

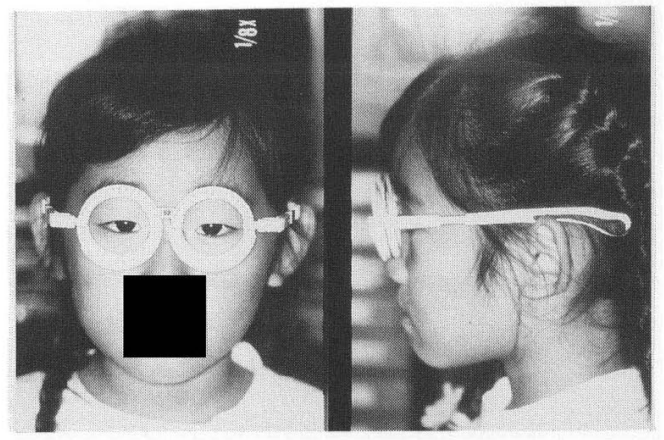

図 9.新しい検眼用フレームの装用例

\section{文献}

1 ）中村桂子：乳幼児の眼鏡. あたらしい眼科： $5: 913-944,1988$.

2) 山崎弘仁：フレームの知識. 眼鏡p. $1-20$, （株）メデイカル葵出版（1986）.

3 ）日本光学工業株式会社 眼鏡営業部：フレー ム材料. フレーム種類と各部名称. メガネレ ンズとフレームの知識 p. 118-126.

質問 (三城光学研究所 内田 讶子)

1. 最小サイズが 50 ミリになっているが，乳幼児 は50ミリでは足りないと思う。

43 ミリぐらいからのサイズが必要かと思う が，50ミリ以下のサイズを作っているのかど うか，扮聞きしたい。また，逆に68ミリのサ イズはどのような患者に対応するのか，大人 でも使える様にという意味でっくったのでし ようか?

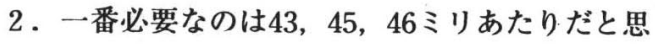
いますが，モダンを少し短くするなどの方法 で，小さなサイズも検討してもらえるとあり がたいと思います。逆に，大人では最近体格 が良くなっており，最大 68 ミリでは足りない と思うので, 74 ミリぐらいまで幅を広げても らえると非常にありがたいと思います。

\section{答弁}

1.レンズホルダーを頑丈にしたため，PD48ミリ 以下ではのレンズホルターがぶつかってしま い，50ミリまでが限界となりました。

2. 大人の方にも装用してもらえるように, $\mathrm{PD}=$ 68ミリまで作りました。

質問 （近畿大 松本富美子）

1. 試作フレームの消毒はどのような方法で可能 でしょうか?

答弁

1. 本体は高温に耐えることができますので，煮 沸消毒が可能ですが，残念ながら鼻パッドは 60度が軟化点ですので, 煮沸消毒はおすすお できません。 E K Cの場合，鼻パットはとり 
はずしができますし，又交換して頂いた方が 安心かと思います。

追加（大阪市立総合医療センター 田中 尚子）

1.よく考案されたフレームだと思いますが，普
及させるためには利用者のニーズが必要なの で, 他のメーカーにも働きかけて, 出来るだ け安価な改良品が多く出回ることが望まれま す。 